\title{
Somewhere over the rainbow: Italy and the regulation of same-sex unions
}

\author{
Alessia Donà* \\ Department of Sociology and Social Research, University of Trento, Italy
}

(Received 11 August 2020; final version accepted 6 April 2021)

\begin{abstract}
While almost all European democracies from the 1980s started to accord legal recognition to same-sex couples, Italy was, in 2016, the last West European country to adopt a regulation, after a tortuous path. Why was Italy such a latecomer? What kind of barriers were encountered by the legislative process? What were the factors behind the policy change? To answer these questions, this article first discusses current morality policymaking, paying specific attention to the literature dealing with same-sex partnerships. Second, it provides a reconstruction of the Italian policy trajectory, from the entrance of the issue into political debate until the enactment of the civil union law, by considering both partisan and societal actors for and against the legislative initiative. The article argues that the Italian progress towards the regulation of same-sex unions depended on the balance of power between change and blocking coalitions and their degree of congruence during the policymaking process. In 2016 the government formed a broad consensus and the parliament passed a law on civil unions. However, the new law represented only a small departure from the status quo due to the low congruence between actors within the change coalition.
\end{abstract}

Keywords: same-sex unions; party politics; morality politics; LGBT mobilisation; Catholic Church; veto players.

\section{Introduction}

The regulation of same-sex couples has reflected common issues among European states. Starting from Denmark in 1989 - where for the first time same-sex couples were recognised with the introduction of registered partnership legislation - the process of legal recognition of same-sex unions (SSU) expanded in the last three decades across European states. However, until very recently Italy was considered as a laggard, being the only Western European country without any kind of formal recognition of same-sex couples. Eventually in 2016 Italy adopted civil union legislation (known as the Cirinnà law after the name of the MP who proposed it), which accorded most of the same rights as marriage but excluded adoption rights. As Ruiu and Gonano $(2020,1192)$ observed: 'This law represented a compromise between Catholic conservatism and left-wing progressivism'. Nevertheless, the Cirinnà law marked a significant policy change for Italian Catholic society, with its conservative and heteronormative views on sexuality and family relations (Lasio and Serri 2019).

How did this policy change occur? Why did the issue of regulating same-sex couples become so intensely politicised? What were the factors affecting the Italian progress towards the enactment of a civil union law? How did the $\mathrm{LGBT}^{1}$ struggle for rights arise? Who were the actors who

\footnotetext{
*Email: alessia.dona@unitn.it
}

(C) The Author(s), 2021. Published by Cambridge University Press on behalf of the Association for the Study of Modern Italy. This is an Open Access article, distributed under the terms of the Creative Commons Attribution licence (http://creativecommons.org/licenses/by/4.0/), which permits unrestricted re-use, distribution, and reproduction in any medium, provided the original work is properly cited. 
sustained and opposed it? In addressing these questions public policy researchers refer to the political science literature on morality issues. Morality policies are 'a set of public issues that provoke fierce debate over the "right way" of living' (Euchner 2019, 1). Morality policy analysis is a young and growing research field, different from classical policy issues given that it concerns fundamental values such as life, death and the meaning of family (Studlar, Cagossi and Duval 2013). Often these discussions evidence the role of religion, religious actors and religious argument. Hence my analysis takes into account not only the role of political parties in promoting or blocking policy change but also the Catholic Church and the LGBT movement as relevant societal actors with the potential power to influence SSU policymaking.

The aim of this article is to shed light on the 2016 legislative process, whose outcome was a policy change for a conservative country like Italy. Although the SSU comparative literature is very rich and useful (Paternotte and Kollman 2013; Paternotte and Tremblay 2015), these contributions do not provide an interpretative framework which might allow a comprehensive understanding of both the SSU policy trajectory and underpinning sociopolitical dynamics. Hence, the reason for a close analysis of the Italian case is to provide an understanding of the Italian policy trajectory of SSU regulation. In doing so, I focus on two main periods: the phase of the entrance of the SSU issue onto the political agenda and the policy failure during the Prodi II government (2006-08); and the phase of SSU legal enactment during the Renzi government (2014-16).

The theoretical framework builds on Tsebelis's veto player theory (2002) as revised by Schmitt, Euchner and Preidel (2013) to include - alongside political parties - societal actors conceived as additional veto players, and hence to provide an analytically oriented reconstruction of the SSU policy process in Italy over the last 20 years. In identifying the factors explaining the 2016 policy change, I analyse the interplay between political parties and societal actors, including the role of the Vatican and the LGBT movement as key players in mobilising support - respectively - against and in favour of SSU. The article will show that the specific features of domestic sociopolitical dynamics represent a key to understanding the Italian SSU path from the policy failure in 2008 to the adoption of a permissive policy in 2016.

This article thus contributes to the morality policy literature on SSU. First, it addresses the dynamics between partisan and societal veto players in implementing policy change. Second, it enriches our understanding of the country-specific process of SSU regulation. Third, it evidences the contested nature of SSU in a conservative country such as Italy, where LGBT rights remain vulnerable and contested. The article is structured as follows. The first section presents an overview of the morality policy literature and provides insights into the theoretical debate and the key concepts employed in my analysis of the Italian case. The second section explains the theoretical approach, methodology and research material. The third section provides a reconstruction of the Italian SSU policy trajectory over the last two decades. The conclusion discusses the main findings and delineates future lines of research.

\section{Morality issues at stake: explaining the variety of SSU regulation in Europe}

In the academic literature scholars have referred to morality issues when talking about abortion, same-sex partnership, prostitution, euthanasia, embryo research and assisted reproductive technology, among other public policy topics. These issues provoke a political and public debate involving value conflicts over first principles and right and wrong ways of living. Hence the main research question driving research on morality issues is the following: do morality issues differ from non-morality issues in terms of the policymaking process? Starting from the United States in the late 1990s (Mooney 2001) and expanding to Europe in the early 2000s, this research 
field has investigated the role of traditional factors in explaining morality policy change, generally through extensive comparative analysis or single case studies (for a review see Euchner 2019).

Concerning the specific SSU issue, over the last 30 years new legal family institutions have been recognised in Europe and have been made available to same-sex couples (Waaldijk 2017). Hence we can find equal marriage, civil union and cohabitation. The main criteria to distinguish between the different family institutions are the following: the legal name used for it, the procedure to be followed, the rights granted to same-sex couples according to the national form of legal recognition, and the general similarity to marriage. According to scholars (Winter, Forest and Sènac 2018), as a legal institution equal marriage can be characterised as a form of partnership between two persons of the same sex that is created by a formal act of registration, and that results in a number of legal rights and obligations (both between the partners and between the partners and others, including the state), equal to marriage. Civil union (alternatively called registered partnership) is a legal institution similar to marriage given the fact that a registration procedure is required, the couple acquires civil status and rights and obligations are recognised for the two partners. Finally, cohabitation refers to a contract signed between two persons who are cohabitants. In most member states of the European Union, and in a handful of other European countries, at least one form of legal recognition is now available to same-sex couples. Moreover, it seems that European countries are diverging less than they did a few years ago (see Table 1). The majority of European countries have introduced a legal recognition that is either called marriage or that entails almost all of the legal consequences of marriage; while in a few countries this is not yet the case, some of the rights of marriage are available to same-sex couples who choose to register a civil union or a partnership. To address the variety of national legal recognitions and the timing of law enactment on SSU across Europe, scholars have analysed the role of domestic factors. So far the explanatory factors of SSU change have included traditional domestic factors such as the cleavage structure and the party system, the organisation of the institutional context, and religious and public attitudes on sensitive issues (for a comprehensive review see Pettinicchio 2012; Digois 2020).

In this literature Italy has been described as the exceptional case due to the fact that until very recently it was among those European countries without any kind of SSU legalisation and the only one in Western Europe. Some scholars have argued that this delay was the result of the peculiar power and political influence of the Catholic Church, which strongly opposed the process of SSU regulation in order to maintain the heteronormative status quo, leaving LGBT issues almost neglected (Knill, Preidel and Nebel 2014). Italian scholars have confirmed the role of the Vatican as a very active interest group able to influence domestic policymaking in a restrictive way in many fields other than LGBT rights, such as immigrants' rights, reproductive rights and euthanasia (Ceccarini 2008; Marzano and Urbinati 2013). Other researchers have pointed to the role of the religious factor and in particular the religious characteristics of the nation (Engeli, Green-Pedersen and Larsen 2013). Because Italy is a society where the dominant religion is Roman Catholicism, the lack of recognition for LGBT people's rights has been explained as a consequence of the dominant Catholic discourse promoted by a catechism centred on the defence of the traditional 'natural' family and the disapproval of homosexual conduct as contrary to natural law (Zaccaria 2015).

However, the picture is more complex. A close analysis has revealed that the religious factor has acted more as a brake than an impediment, meaning that in Catholic societies morality issues are discussed, debated and decided with a different progression in comparison to non-Catholic societies. For example, Knill, Preidel and Nebel (2014) found that the Catholic Church influenced the speed and content of policy reform in Catholic states such as Spain, where it took more time to adopt permissive legislation, namely the law on same-sex marriage in 2005. Moreover, if 
Table 1. Dates of SSU legislation in Europe: access for same-sex partners to marriage or registered partnership/civil unions. Source: Human Rights Watch, LGBT Rights (last updated July 2020). Map of LGBT Rights available here: http://internap.hrw.org/features/features/marriage_equality/

\begin{tabular}{|c|c|c|}
\hline Country & Registered parnership/Civil unions & Equality marriage \\
\hline Denmark & $1989-2012$ & 2012 \\
\hline Norway & 1993-2009 & 2009 \\
\hline Sweden & 1995-2009 & 2009 \\
\hline Iceland & $1996-2010$ & 2010 \\
\hline The Netherlands & $1998-2001$ & 2001 \\
\hline France & $1999-2013$ & 2013 \\
\hline Belgium & $2000-2003$ & 2003 \\
\hline Portugal & $2001-2010$ & 2010 \\
\hline Germany & $2001-2017$ & 2017 \\
\hline Finland & 2002-2017 & 2017 \\
\hline Croatia & 2003 & No \\
\hline Luxemburg & 2004-2015 & 2015 \\
\hline England and Wales (UK) & 2005 & 2014 \\
\hline Scotland (UK) & 2005 & 2014 \\
\hline Northern Ireland (UK) & 2005 & 2020 \\
\hline Switzerland & 2006 & No \\
\hline Spain & No & 2005 \\
\hline Czech Republic & 2006 & No \\
\hline Austria & 2009-2019 & 2019 \\
\hline Hungary & 2010 & No \\
\hline Ireland & 2011-2015 & 2015 \\
\hline Malta & 2014 & 2017 \\
\hline Greece & 2015 & No \\
\hline Italy & 2016 & No \\
\hline Estonia & 2016 & No \\
\hline Slovenia & 2016 & No \\
\hline
\end{tabular}

Protestant/non-Catholic countries have been seen to adopt SSU legislation quicker than Catholic countries, in 2010 the difference between Catholic and non-Catholic countries disappeared, because by that year all European countries had adopted legal recognition of same-sex couples, with the sole exception of Italy. Hence, religion alone is not sufficient to explain the lack of legal recognition of same-sex couples (Pettinicchio 2012).

The same goes for the acceptance of homosexuality or the degree of homophobia, for which again - religion is a factor that has acted more as a brake than a complete hindrance (Hildebrand, 
Trüdinger and Jäckle 2017). Scholars have found that the more tolerant the society (for example in Norway, Sweden and Denmark), the more easily and quickly SSU legislation has been adopted; however, even countries with a less tolerant population have introduced some form of recognition of SSU. For example, in countries such as the Netherlands, Belgium, Spain and Portugal, one can observe that left-wing or secular political parties have implemented SSU policy, despite the low level of public acceptance (Hooghe and Meeusen 2013). Hence, attention is turned to the role played by the political system in legalising SSU.

The strand of research focusing on the role of political parties in morality policymaking has found that ideological colour affects policy change. While left and secular parties tend to support liberal values and promote SSU regulation (Budde et al. 2017), conservative and confessional parties tend to oppose and block the country's path towards permissiveness in morality policy (Engeli, Green-Pedersen and Larsen 2013). Other studies have addressed the relevance of congruence in issue positions within the government coalition (Varone, Rothmayr and Montpetit 2006); this means that in the case of substantial disagreement between government actors, a process of nondecision or postponement is likely to occur. Some scholars have included the power dynamics between the change and blocking coalitions in the legislative arena (Schmitt, Euchner and Pridel 2013), combined with the features of the institutional setting (type of regime, point of access to decision making and so on). In this case, a policy change is likely to occur when a change coalition - comprising political and societal actors - is able to neutralise veto points and counteract the blocking coalition whose preferences favour the status quo. Hence domestic party systems and sociopolitical dynamics do indeed make a significant difference in explaining the variety of SSU regulation (in timing and in legal institutions) across European countries.

Against this backdrop, the present analysis focuses on the case of Italy to explain the end of Italian exceptionalism in 2016, when a form of recognition for same-sex couples was introduced under the legal institution of civil unions. This empirical investigation addresses the SSU policy process from the 2008 failure to the 2016 policy change. I argue that the Italian trajectory of SSU regulation can be understood by considering the role of partisan and societal actors as relevant players, as both promoting and blocking change, during the policy-making. My hypothesis is that the balance of power between coalitions promoting and blocking change during the policy-making process has shifted over time according to the different institutional settings. Hence, other research questions followed: in comparison to policymaking in 2008, what were the institutional conditions under which the 2016 Cirinnà law was approved? Did the ideological in/congruence among government actors increase over time? How did the coalitions' composition differ in the two periods? What was the relationship between partisan actors and societal actors? The next section explains the methodology and research material informing my analysis.

\section{Theoretical approach, methodology and data}

This article proposes using George Tsebelis's (2002) veto player theory to conceptualise the actors' role in affecting policymaking. According to Tsebelis $(1995,293)$, 'a veto player is an individual or collective actor whose agreement is required for a policy decision'. The institutional features play a decisive role in determining the conditions for coalition building because they define the veto points, meaning the access points to the policymaking. For the status quo to change, a certain number of individual or collective decision-makers have to agree to this change. Hence the policy stability of a political system increases with the number of veto players able to block a decision, and it increases when the ideological incongruence between actors is high in a context of multiple veto actors. In sum, the more veto actors, the more difficult the formation of a change 
coalition. Conversely, when the number of veto actors decreases and a change coalition is large and congruent, then a radical policy change may occur.

While in Tsebelis's formulation, veto players are basically parties and institutions, following the work of Fink (2009), Schmitt, Euchner and Preidel (2013) and Potz (2020), I conceptualise parties and societal actors as veto players. Specifically, I consider as units of analysis the coalitions of actors: on one side, the change coalition comprises actors whose preferences are in favour of the policy change; on the other side, the blocking coalition covers all actors whose goal is policy stability or the status quo. In both periods under study a left-wing government was in power, namely the Prodi II government (2006-08) and the Renzi government (2014-16). In analysing SSU policymaking, I consider the institutional setting (for instance, the fragmentation of parliament, majority stability), the government actor's congruence in promoting the policy initiative and the balance of power between the change and the blocking coalitions.

In the issue under discussion, veto players as societal actors involve the Catholic Church and its fellow organisations on one side and the LGBT movement and other associations on the other side. These actors, acting in their role of societal veto players in alliance with their institutional or partisan counterparts, may play similar roles of promoting, blocking and constraining political change. In our case study, the effort to advance LGBT rights produced the Vatican's opposition to legal recognition for alternative models of families, considered as a challenge to the sacredness of heterosexual marriage. Hence religious actors may represent strong veto players whose ability to block the policy change is constrained by their opportunities to access the political system. As other scholars have found (Knill and Preidel 2015; Schmitt, Euchner and Preidel 2013), party system fragmentation and the unstable majority in parliament during the Prodi II government meant multiple access points for the Catholic Church and its fellow partisans to influence the political debate and block the regulation of SSU.

So far very few policy studies on the Italian SSU policy process have acknowledged the role of the Italian LGBT movement as a societal actor (with the notable exceptions of Guaiana and Seymour 2019 and Danna 2018). My analysis contributes to partially fill this lacuna by referring to the emerging literature on the Italian LGBT movement and its organisation (Prearo 2015; Cristallo 2017; Pedote and Poidimani 2020) to provide a comprehensive analysis of Italian policymaking. I argue that the existence and activities of the LGBT movement is crucial but not sufficient to advance LGBT people's rights. As my study will show, for LGBT associations to obtain real policy change, they need to succeed at mobilising public support and framing LGBT issues in a coherent and cohesive way, and to establish strong connections with national-level parties.

Methodologically, the empirical analysis presented in this article relies on detailed process tracing of the policy reform trajectory in a single case study (Trampusch and Palier 2016) in order to specify causal and temporal mechanisms of the Italian steps towards SSU recognition. Previously the single case study methodology was used in the case of the Netherlands, the first country to allow same-sex couples to marry in 2001 (Kollman 2017). The empirical case study is based on the following sources: parliamentary debates and text legislation, LGBT official documents, Vatican statements, media coverage, and secondary literature.

\section{The Italian move to civil unions legislation: actors, coalitions and power}

The first bill on the recognition of same-sex couples dates to 1988, when socialist deputy Alma Agata Capiello presented a text to regulate the de facto family, including both heterosexual and homosexual relationships. A second bill was presented in 2002 by left-wing (Democratic Party of the Left) senator Franco Grillini, then president of the National Association of Gays and 
Lesbians, Arcigay. The text aimed to recognise civil and de facto partnerships based on a contract between two persons for the purpose of organising relevant aspects of their shared life. The two bills never reached the parliamentary floor, but they fuelled a public and political debate.

Over the years the SSU issue became more and more a contentious issue dividing the progressive positions of leftist parties promoting SSU regulation and the centre-right coalition, with minor Catholic parties opposing any departure from the legislative status quo (Ceccarini 2008). In the meantime the LGBT movement became a visible actor after the successful 2000 Pride march held in Rome during the papally declared Jubilee year. With that event the movement realised that the mobilisation could be translated into political activism to claim LGBT rights, including same-sex partnership (Guaiana and Seymour 2019). On the other side, the Catholic Church remained a relevant actor within national politics. After the fragmentation of the Church's historical ally, the Christian Democratic Party, the Church acted as a veto player with its strong mobilisation potential, internal cohesion and clear preferences on issues regarding the right to life (and death) in its various facets and the bio-political agenda, covering the use of stem cells, artificial insemination, abortion, the so-called abortion pill (RU-486), the living will and euthanasia, transplants, and cloning. For example, its position against any experimentation involving the human embryo (Pontifical Academy for Life 2000) was absorbed into the embryo-research political debate, on which the Catholic Church had taken a firm position (Diamanti and Ceccarini 2007). Initially the Church was able to obstruct the passage of a permissive law on embryo research during the left-wing secular government (1996-2001) and then to affect the content of the restrictive law 40/2004 on assisted reproductive technologies approved by the centre-right conservative government (2001-06).

Similarly, the question of the family, its transformations, and the different possible forms of recognition for same-sex couples became a more and more a contested issue in the early 2000s. In this scenario, the role of the Catholic Church can be conceptualised as a societal veto player whose power is based on mobilisation potential and internal preference cohesion and on strong ties with the right-wing coalition in mirroring its positions against SSU. On the other side, the LGBT movement can be conceptualised as a societal actor that was increasingly visible, mobilising support and entering the political arena directly through the election of its main activists within the ranks of the left-wing parties (for example, the already mentioned Grillini, but also Paola Concia, Sergio Lo Giudice, Nichi Vendola, Vladimir Luxuria and Ivan Scalfarotto).

In the following paragraphs - keeping in mind the veto player theory - I present the main features of the political context in the two remarkable steps of the Italian process towards SSU recognition, namely the 2007 bill on cohabitation (Donà 2009; Ceccarini 2008; Ozzano 2015) and the 2016 enactment of the Cirinnà law (Ozzano 2020; Lasio and Serri 2019) by evidencing the power dynamics between the change and blocking coalitions. In doing so I differentiate between two patterns of morality policymaking and the relative content of the policy initiative.

\section{The 2007 DICO bill}

In February 2007 a bill regarding the legal rights of stable unmarried couples, including same-sex couples, was promoted by the centre-left government led by Romano Prodi (2006-08). The recognition of same-sex couples was a contested issue in the campaign for the elections of 9-10 April 2006 in a political context of fragmented bipolarism (D'Alimonte 2005). On the one hand the right-wing coalition House of Freedoms (Casa delle Libertà, comprising Forza Italia, Alleanza Nazionale, Lega Nord and small conservative parties) posed as the defender of the traditional family and the guarantor of Catholic values. On the other hand, the left-wing coalition 
Union (Unione), whose main components were the Left Democrats (DS) and the Christian progressive party Margherita together with smaller leftist and centrist parties, included in its electoral manifesto - in a consciously vague way in order to hold the reformist and Catholic components together - proposals for recognition of the relationships of unmarried couples.

The government-sponsored bill named DICO (Diritti e Doveri delle Coppie Conviventi, rights and duties of cohabiting partners) recognised the rights and obligations of cohabiting couples. Despite being a weakly worded statement of same-sex couples recognition, it evoked strong opposition from the Assembly of Italian Bishops (CEI) and its president, Cardinal Camillo Ruini. In an official note, the CEI reminded Catholic politicians of Church teaching, calling on them not to support

measures that compromise or undermine defence of the ethical requirements essential for the common good of society .... and to defend non-negotiable values. [These refer to] respect for, and defence of, human life, the family based on marriage between a man and a woman, freedom of education for children, and the promotion of the common good in all its forms. The Catholic parliamentarian has the moral duty to express clearly and publicly his/her opposition and to vote against any bill that might offer recognition to gay partnerships (Official Note of the Episcopal Conference of Italy, 28 March $\left.2007^{2}\right)$.

Previously, on 13 March 2007 in his 'Esortazione Apostolica Post-sinodale', Pope Benedict XVI himself intervened publicly to oppose the bill.

The Vatican hierarchy in the role of veto player found multiple access points for influencing policy-making. The centre-left coalition won the 2006 general election by a tiny majority, and three aspects were particularly relevant for the bill's trajectory in 2008. First, the distribution of seats in the two houses of parliament meant that the centre-left had an extremely narrow majority in the Senate. Second, the centre-left government coalition included some members coming from the political culture of democratic Catholicism and who were very close to the Catholic Church's positions. Third, the Catholic members of Union tended to ally with Catholic representatives elected in the centre-right coalition and form a bipartisan axis in relation to ethical issues. Hence, during the DICO bill debate the Catholic component inside the centre-left coalition was an influential minority with considerable veto power to oppose the legislative initiative given the centre-left's precarious grasp on the Senate (Ceccarini 2008).

The LGBT movement and organisations decided not to enter into the policy debate, due to the fact that the bill under discussion was far from the preferred goal of marriage equality, and hence the text was fiercely criticised by some of the leading activists ${ }^{3}$. So the DICO bill was supported by a minority change coalition composed of left-wing and secular parties, while the Union's Catholic members became partisan veto players by joining the broad blocking coalition comprising the right-wing coalition and the Catholic Church. The blocking coalition delayed the discussion in parliament and shelved the text until the fall of the Prodi II government in January 2008 (Guaiana and Seymour 2019). The victory of the right-wing coalition in the 2008 elections meant the disappearance of the SSU issue from the political agenda in the following years.

\section{The 2016 Cirinnà law}

In 2016 the parliament passed a law which allowed same-sex unions in Italy. The general election of March 2013 registered the unexpected rise of the newcomer populist anti-establishment party Movimento 5 Stelle (M5S, Five Star Movement). Since none of the competing parties reached the necessary majority to form a government, a national unity government led by Enrico Letta (2013-14) was formed based on the partnership of the Democratic Party (PD, resulting from 
the union of the former DS with the moderate Margherita) with (some parts of) Forza Italia and other minor parties, while Lega Nord and Fratelli d'Italia (formerly Alleanza Nazionale) maintained fierce opposition against the government, together with M5S. As happened in 2006, the government coalition was based on a highly fragmented parliamentary majority with low numbers in the Senate.

In the meantime the political activism of pro-LGBT societal actors claiming rights for samesex couples and parenting increased. Specifically, a coalition of LGBT organisations, feminist associations, civil rights associations (such as Amnesty International) and trade unions (CGIL, CISL) started to actively advocate for the introduction of SSU legislation. Moreover, the two legal advocacy associations for the advancement of LGBT rights - Rete Lanford, founded in 2007, and Associazione Radicale Certi Diritti, founded in 2008 - jointly launched the campaign Affermazione Civile and started a litigation strategy to eliminate discrimination against lesbian, gay and bisexual people before domestic and international courts (Guaiana and Seymour 2019; Ruiu and Gonano 2020). As a result, in 2015 the European Court of Human Rights condemned Italy for not recognising the rights of sexual minorities, ${ }^{4}$ and this acted as external pressure on Italy to intervene on SSU (as previously occurred in other European countries, Roseneil et al. 2013). As part of these advocacy activities, prominent LGBT activists elected to parliament started to advance bill proposals on LGBT issues (Lavizzari and Prearo 2019).

To promote same-sex couples' rights, at the start of the legislature the PD senator Monica Cirinnà, together with her party mate Sergio Lo Giudice, former president of Arcigay, presented a far-reaching bill on marriage equality. This initiative became part of a general discussion on a new bill proposal prepared by Cirinnà herself in her role of rapporteur and resulting from the merging of different bills at the time under discussion in parliament. In the meantime, the Letta government resigned and was replaced with a new centre-left government under Matteo Renzi (201416), leader of the PD and committed to introducing legislation on SSU. At this stage, the Senate's working committee registered a close collaboration between senators from PD and M5S (which was not part of the majority). In agreeing on a common text, the two parties fought against the resistance of opposition right-wing parties and some members of government parties. Inside the government, the main opponents were some Catholic PD members and Minister Angelino Alfano, leader of the Nuovo Centro Destra (NCD, New Centre Right). The NCD was a new party composed of many former Popolo della Libertà (PdL) members after Silvio Berlusconi had decided in 2014 to withdraw his support for the Renzi government. Alfano's party retained an important political position in securing a majority in the Senate; however, his potential veto power - at that time - was neutralised by the support of M5S for the Cirinnà bill.

The text under discussion recognised civil union for same-sex couples and the adoption right for the second parent (stepchild adoption). This latter element was the object of lively debate, which caused a deep fracture between the feminist and LGBT movements on surrogacy motherhood (Cossutta 2018). While for the promoters it was a way to regularise existing family bonds, for its opponents it would have opened the door to surrogate motherhood (Danna 2018). It was clear that within civil society it was a divisive issue when some feminists in the movement 'Se non ora quando - Libere' launched in December 2015 a petition to call for an international ban on surrogacy. ${ }^{5}$ LGBT activists signed the petition too, while other feminist groups strongly criticised it because it marked the end of the cohesion and congruence of the pro-LGBT movement, undermining the large support for the entire bill proposal. Hence, on 23 January 2016 some parts of the pro-LGBT movement mobilised in more than 100 towns with the slogan 'Wake up Italy, it's time to be civili' to support the bill proposal. 
Considering the role of the societal actor opposing LGBT rights, this time the Catholic Church too was less active and cohesive in influencing SSU policymaking. While Pope Francis promoted a more merciful and tolerant tone on the issue and refrained from interfering directly in the Italian debate, Cardinal Angelo Bagnasco, president of the CEI, encouraged Catholics to join opponents of the legislation. A constellation of religious and conservative actors (known as an Italian antigender movement, Lavizzari and Prearo 2019) organised on 20 June 2015 and then on 30 January 2016 Family Day events, held in Rome with the participation of Catholic pro-family organisations but without the official endorsement of the Vatican. The rally organisers aimed to block the legislative initiative and to oppose a gender ideology (ideologia del gender, Spallaccia 2020) that they accused of challenging traditional gender roles and children's right to have a father and a mother. Centre-right parties supported the event, while the minister Alfano endorsed the opposition to the initiative and became the representative of the Catholic position inside the Renzi government.

If inner fragmentation of the societal actors was already evident, even the partisan partnership between PD and M5S abruptly ended when in early February 2016 - a few days before the floor discussion and vote in the Senate - the leader of M5S, Beppe Grillo, posted on a blog that the vote on SSU, being an ethical and constested issue, would be a vote of individual freedom of conscience. ${ }^{6}$ This meant that the bill's approval would probably be questionable in the Senate, due to the slim parliamentary majority. Prime Minister Renzi decided to turn to his junior ruling coalition partner for support, but NCD's support was conditional on the PD dropping the stepchild adoptions clause, the fidelity requirement and other minor points. Hence, to avoid a governmental crisis, Renzi proposed a new text which integrated the preferences of NCD and put it under a confidence-vote procedure. Eventually the revised text was approved by the Senate on 25 February 2016, and this represented a turning point for the policy process, given that in the Chamber of the Deputies the government was sustained by a much larger majority.

\section{Conclusion}

This article has contributed to our understanding of the policy dynamics in reference to the recognition of LGBT rights. The empirical analysis of the Italian progress towards the regulation of SSU evidenced the necessity for a broad consensus supporting a government initiative to bring policy changes. By adopting a theoretical framework centred on the sociopolitical dynamics and conceiving partisan and societal actors as veto players, I have analysed the policy process during the Prodi II (2006-08) and Renzi (2014-16) governments and assessed the balance of power between change and blocking coalitions to explain the different policy outcomes.

In the case of the Prodi II government, the blocking coalition was able to increase the number of veto players by including some Catholic government actors opposing the 2007 bill on cohabitation. Hence, the change coalition found a reduction in its numbers, while the enlarged blocking coalition succeeded in imposing a delay and dilution of the bill until the fall of the government. The resulting policy failure of the DICO bill was due to an institutional context, where the Catholic Church acted as a coherent and resolute veto player and successfully interfered with the policymaking to block the decision. On this occasion, the LGBT movement was not active in supporting the government initiative given its preference for an instrument of marriage equality for same-sex couples rather than of cohabitation.

During the Renzi government, the change coalition was able to neutralise partisan veto actors to approve the 2016 law on civil unions. However, the necessity to obtain support from the NCD 
reduced the degree of policy coherence within the government, with the result that the policy change was incremental. In a context of party fragmentation and a small parliamentary majority, the Cirinnà law represented the result of a compromise between government parties with different preferences, namely PD and NCD. In line with the PD's preferences, the new law recognised rights for same-sex couples similar to the institution of heterosexual marriage in the area of patrimonial regime, inheritance, reciprocal moral and economic assistance, dependant leave and immigration (Lasio and Serri 2019). However, in line with the NCD's preferences, the law avoided the recognition of gay and lesbian parenting and mentioning the 'family' word. Same-sex couples are not legally allowed either to adopt children or to use medically assisted procreation. The law recognised same-sex couples as social units (formazioni sociali) as defined in Article 2 of the Constitution. The intention was clearly to exclude any link with Article 29 of the Constitution, which recognises and safeguards families founded on marriage between a man and a woman. Moreover, to further mark the difference with heterosexual marriage, in the case of civil union a period of separation is not required by law before its dissolution, and there is no fidelity obligation. Concerning the societal actors, while pro-LGBT movements and organisations showed divergent positions on the contested issue of stepchild adoption, the Catholic Church was less cohesive and resolute in opposing the approval of the bill. In this way, both actors reduced their potential veto power on the majority's determination to approve the bill.

In sum, these findings confirm that partisan politics matter in morality issues such as SSU. Moreover, the Italian case study revealed some aspects of the LGBT struggle for rights that require further investigation. First there is the relevance of the courts and their role in removing discriminatory legislation against LGBT people. The way the Italian LGBT movement uses strategic litigation to influence policymakers and mobilise constituencies is still an understudied field from a political science perspective. The decision to adopt a rights-based approach in demanding anti-discrimination legislation and partnership rights may represent a new mode of LGBT activism beyond the traditional strategies of protests, pride marches, mass mobilisation, lobbying and so on. Alternatively, this could signify a process of organisational differentiation within the movement. Second, the fracture between the LGBT and feminist movements about parenting rights has not disappeared after the approval of the law on civil union. The LGBT movement (or the major part of it) continues to demand marriage equality and parenthood rights. Thus, a divergence between the different identities of the movement would likely re-emerge in the future. Third, LGBT rights remain contested and fragile in Italy. In times of right-wing populism and religious anti-equality movements, attacks against gender equality and LGBT people have increased across European countries. Italy has not been immune to this phenomenon: while the populist radical right Lega party was in power during the Conte I government (2018-19), many initiatives were launched against LGBT people (Donà, 2021). This means that the composition of the Italian blocking coalition has changed over time according to the transformation of the party system and the constellation of conservative and religious actors (Prearo 2020). Against this backdrop, Italy remains an interesting case study for future research.

\section{Note on contributor}

Alessia Donà is Associate Professor of Political Science at the University of Trento, Italy. Her main areas of research are gender politics and policy making, human rights and LGBT+ issues, and the gender dimension of global governance. 


\section{Notes}

1. Note that I adopt the widely used 'LGBT' acronym for Lesbian, Gay, Bisexual and Transexual. It is an umbrella term to cover the whole community with the inclusion of other varieties of gender identity (queer, intersexual, asexual).

2. The text of the CEI Note (in Italian) can be found here: https://www.corriere.it/Media/Foto/2007/03/28/ Nota_cei.pdf

3. See the note of criticism written by the then president of Arcigay, Sergio Lo Giudice, and posted on the institutional website, retrievable here: https://www.arcigay.it/archivio/2007/02/10-regole-per-migliorareil-dico/\#.X_b60hbSI2w (last accessed 7 January 2021).

4. The European Court of Human Rights (ECoHR) ruled against Italy in the Oliari case (21 July 2015, Oliari v. Italy), ruling that the absence of a legal framework recognising homosexual relationships violated the right to respect for privacy and family life as provided by Article 8 of the European Convention of Human Rights.

5. The text of the petition in Italian can be found here: http://www.cheliberta.it/2015/12/04/appello-cheliberta/

6. See Beppe Grillo's post (in Italian) here: https://www.ilblogdellestelle.it/2016/02/si_alle_unioni_civili_liberta_di_coscienza_per_la_stepchildadoption.html

\section{References}

Budde, E., S. Hechel, S. Hurka and C. Knill. 2017. 'Partisan Effects in Morality Policy Making'. European Journal of Political Research 57: 427-449.

Ceccarini, L. 2008. 'Civil Unions and Political Divisions'. In Italian Politics. Frustrated Aspirations for Change, edited by M. Donovan and P. Onofri, 213-33. New York: Berghahn Books.

Cossutta, M. 2018. 'Maternal Relations, Feminism and Surrogate Motherhood in the Italian Context'. Modern Italy 23 (2): 215-26.

Cristallo, M. 2017. Uscir fuori. Dieci anni di lotte omosessuali in Italia: 1971-1981. Rome: Sandro Teti editore.

D'Alimonte, R. 2005. 'Italy: A Case of Fragmented Bipolarism'. In The Politics of Electoral Systems, edited by M. Gallagher and P. Mitchell, 253-76. Oxford: Oxford University Press.

Danna, D. 2018. 'The Italian Debate on Civil Unions and Same-Sex Parenthood: The Disappearance of the Lesbians, Lesbian Mothers, and Mothers'. Italian Sociological Review 8 (2): 285-308.

Diamanti, I. and L. Ceccarini. 2007. 'Catholics and Politics after the Christian Democrats: The Influential Minority'. Journal of Modern Italian Studies 12 (1): 37-59, DOI: $10.1080 / 13545710601132912$

Digois, M., ed. 2020. Same-Sex Families and Legal Recognition in Europe. Berlin: Springer.

Donà, A. 2009. 'From Pacs to Didore: Why Are Civil Partnership Such a Divisive Issue in Italian Politics?' Bulletin of Italian Politics 1 (2): 333-46.

Donà, A. 2021. 'Radical Right Populism and the Backlash against Gender Equality: The Case of Lega (Nord)'. Contemporary Italian Politics, 13 (3), in press.

Engeli, I., C. Green-Pedersen and L.T. Larsen. 2013. 'The Puzzle of Permissiveness: Understanding Policy Processes Concerning Morality Issues'. Journal of European Policy Public Policy 20 (3): 335-52, DOI: $10.1080 / 13501763.2013 .761500$

Euchner, E.-M. 2019. 'Morality Policy'. In Research Encyclopedia on Politics. Oxford: Oxford University Press. https://doi.org/10.1093/acrefore/9780190228637.013.641.

Fink, S. 2009. 'Churches as Societal Veto Players: Religious Influence in Actor-Centred Theories of Policy-Making.' West European Politics 32: 1, 77-96, DOI:10.1080/01402380802509826

Guaiana, Y. and M. Seymour. 2019. 'From Giarre to Civil Unions: The "Long March" for Same-Sex Relationships in Italy'. In From Sodomy Laws to Same-Sex Marriage. International Perspectives since 1989, edited by S. Brady and M. Seymour, 177-81. London: Bloomsbury.

Hildebrandt A., E.-M. Trüdinger and S. Jäckle. 2017. 'Sooner or Later: The Influence of Public Opinion and Religiosity on the Enactment of Laws Recognizing Same-Sex Unions'. Journal of European Public Policy 24 (8): 1191-1210, DOI:10.1080/13501763.2016.1228693 
Hooghe M. and C. Meeusen. 2013. 'Is Same-Sex Marriage Legislation Related to Attitudes towards Homosexuality?' Sexuality Research and Social Policy 10 (4): 258-68.

Knill, C., C. Preidel and K. Nebel. 2014. 'Brake Rather Than Barrier: The Impact of the Catholic Church on Morality Policies in Western Europe'. West European Politics 37 (5): 845-66.

Knill, C. and C. Preidel. 2015. 'Institutional Opportunity Structures and the Catholic Church: Explaining Variation in the Regulation of Same-Sex Partnerships in Ireland and Italy'. Journal of European Public Policy 22 (3): 374-90.

Kollman, K. 2017. 'Pioneering Marriage for Same-Sex Couples in the Netherlands'. Journal of European Public Policy 24 (1): 100-18.

Lasio, D. and F. Serri. 2019. 'The Italian Public Debate on Same-Sex Civil Unions and Gay and Lesbian Parenting'. Sexualities 22 (4): 691-709.

Lavizzari A. and M. Prearo. 2019. 'The Anti-Gender Movement in Italy: Catholic Participation between Electoral and Protest Politics', European Societies, 21 (3): 422-42, DOI:10.1080/ 14616696.2018.1536801

Marzano, M. and N. Urbinati. 2013. Missione impossibile. La riconquista cattolica della sfera pubblica. Bologna: Il Mulino.

Mooney, C. Z., ed. 2001. Public Clash of Private Values: The Politics of Morality Policy. New York: Chatham House.

Ozzano, L. 2015. 'The Debate about Same-Sex Marriage/Civil Unions in Italy's 2006 and 2013 Electoral Campaigns'. Contemporary Italian Politics 7 (2): 144-60.

Ozzano L. 2020. 'Last but Not Least: How Italy Finally Legalized Same-Sex Unions'. Contemporary Italian Politics 12 (1): 43-61.

Paternotte, D. and M. Tremblay, eds. 2015. The Ashgate Research Companion to Lesbian and Gay Activism. London: Routledge.

Patternotte, D. and K. Kollman. 2013. 'Regulating Intimate Relationships in the European Polity: Same-Sex Unions and Policy Convergence'. Social Politics 20 (4): 510-33.

Pedote, P. and N. Poidimani, eds. 2020. We will survive! Storia del movimento LGBTIQ+ in Italia. Milan: Mimesis.

Pettinicchio, D. 2012. 'Current Explanations for Variation in Same-Sex Marriage Policies in Western Countries'. Comparative Sociology 11: 526-57.

Pontifical Academy for Life. 2000. Declaration on the Production and the Scientific and Therapeutic Use of Human Embryonic Stem Cells, Vatican City, 24 August 2000.

Potz, M. 2020. 'Veto Players and Stakeholders: Religion in Polish and American Politics'. In Political Science of Religion. Cham: Palgrave Macmillan. https://doi.org/10.1007/978-3-030-20169-2_6

Prearo, M. 2015. La fabbrica dell'orgoglio. Una genealogia dei movimenti LGBT. Pisa: Edizioni ETS.

Prearo. M. 2020. L'ipotesi neocattolica. Politologia dei movimenti anti-gender. Milan: Mimesis.

Roseneil, S., I. Crowhurst, T. Hellesund, A.C. Santos and M. Stoilova. 2013. 'Changing Landscape of Heteronormativity: the Regulation and Normalization of Same-Sex Sexualities in Europe'. Social Politics 20 (2): 165-99.

Ruiu G. and G. Gonano. 2020. 'Religious Barriers to the Diffusion of Same-Sex Civil Unions in Italy'. Population Research and Policy Review 39: 1185-1203. https://doi.org/10.1007/s11113-02009613-8

Schmitt, S., E.-M. Euchner and C. Preidel. 2013. 'Regulating Prostitution and Same-Sex Marriage in Italy and Spain: The Interplay of Political and Societal Veto Players in Two Catholic Societies'. Journal of European Public Policy 20 (3): 425-41, DOI:10.1080/13501763.2013.761512

Spallaccia, B. 2020. 'Ideologia del gender: Towards a Transcultural Understanding of the Phenomenon'. Modern Italy 25 (2): 131-45.

Studlar, D.T., A. Cagossi and R.D. Duval. 2013. 'Is Morality Policy Different? Institutional Explanations for Post-War Western Europe'. Journal of European Public Policy 20 (3): 353-71.

Trampusch C. and B. Palier. 2016. 'Between X and Y: How Process Tracing Contributes to Opening the Black Box of Causality'. New Political Economy 21 (5): 437-54, DOI:10.1080/13563467.2015.1134465 
Tsebelis, G. 1995. 'Decision Making in Political Systems: Veto Players in Presidentialism, Parliamentarism, Multicameralism and Multipartyism'. British Journal of Political Science 25 (3): 289-325.

Tsebelis, G. 2002. Veto Players. Princeton, NJ: Princeton University Press.

Varone, F., C. Rothmayr and E. Montpetit. 2006. 'Regulating Biomedicine in Europe and North America: A Qualitative Comparative Analysis'. European Journal of Political Research 45: 317-43. https://onlinelibrary.wiley.com/doi/abs/10.1111/j.1475-6765.2006.00300.x

Waaldijk, C. 2017. More and More Together: Legal Family Formats for Same-Sex and Different-Sex Couples in European Countries - Comparative Analysis of Data in the Laws and Families Database. Families and Societies Working Paper Series no. 75. Stockholm: Stockholm University.

Winter, B., M. Forest and R. Sénac, eds. 2018. Global Perspectives on Same-Sex Marriage. A Neo-institutional Approach. Cham: Palgrave Macmillan.

Zaccaria, F. 2015. 'Catholic Church, Young People and Human Rights in Italy'. In Religion and Human Rights. An International Perspective, edited by H.G. Ziebertz and G. Črpić, 93-102. Berlin: Springer Verlag.

\section{Italian summary}

Mentre altre democrazie europee hanno iniziato a riconoscere legalmente le unioni tra persone dello stesso sesso già a partire dagli anni ottanta, l'Italia si segnala per essere l'ultimo paese dell'Europa occidentale ad avere adottato una legislazione in materia. Infatti, solo dopo un lungo e tortuoso processo politico è stata approvata nel 2016 la legge sulle unioni civili (nota anche come legge Cirinnà). Perché in Italia si è registrato un tale ritardo? Quali sono stati gli ostacoli all'introduzione di una legge? E quali sono stati i fattori che hanno poi portato alla legge del 2016 ? Per rispondere a tali interrogativi, il presente articolo prende come riferimento gli studi che si occupano di morality policymaking con un'attenzione specifica alla questione della regolamentazione delle unioni tra persone dello stesso sesso. Sulla base di questa letteratura, l'articolo presenta un'attenta ricostruzione delle varie fasi che hanno portato alla regolamentazione delle relazioni affettive tra persone dello stesso sesso. Da tale ricostruzione emerge il ruolo importante esercitato dagli attori politici e sociali dalla fase dell'entrata in agenda politica fino alla fase dell'approvazione della legge. L'articolo sostiene che il percorso che ha portato alla legge del 2016 è comprensibile alla luce dei rapporti di forza tra i soggetti favorevoli e quelli contrari alla proposta di regolamentazione e al loro grado di accordo interno. A differenza del governo Prodi (2006-08), il governo Renzi (2014-16) è riuscito a costruire una larga coalizione favorevole alla legge sulle unioni civili e in questo modo a neutralizzare la coalizione avversa. Tuttavia, la legge adottata risulta poco innovativa poiché si tratta di un testo di mediazione tra posizioni politiche assai distanti. 